\title{
PEMANFAATAN MEDIA KOMUNIKASI HUMAS PARTAI KEADILAN SEJAHTERA (PKS) DKI JAKARTA DALAM MENINGKATKAN CITRA
}

\author{
Saktisyahputra \\ Manajemen Komunikasi Institut Ilmu Sosial dan Manajemen STIAMI \\ Email : saktinabil@gmail.com
}

\begin{abstract}
The roles and functions of Political Parties have been degraded lately due to negative stereotypes towards Political Parties, including the Partai Keadilan Sejahtera (PKS). It happened because some PKS cadres were caught by the Corruption Eradication Commission (KPK) in mass media coverage. Besides, the formation of Political Parties including the Partai Keadilan Sejahtera (PKS) as the birthplace of national leadership seems to be less than optimal. For this reason, researcher was interested in discussing the use of public relations communication media for PKS through the media in improving the image of the institution. Based on this context, this study aims to determine the utilization of PKS Communication Media in Improving the Image and analyze the factors that support PKS Communication Media Use. This study uses qualitative research methods with data collection techniques in the form of interviews, observation, documentation and literature study. Interviews were conducted on 4 (four) informants representing the PKS Public Relations Division at both the DKI Jakarta Province level and DPC PKS at the Pulogadung District level. The results showed that the utilization of the media for the use of communication media, especially social media by PKS public relations, among others were Photo PKS, TV PKS, Digital Volunteers, Literacy Volunteers, PKS Art, and the creation of short videos advertised. Factors supporting the use of communication media are solid HR PKS cadres and sufficient funding sources to support the use of communication media, especially social media, in reducing the negative stereotypes of the community towards PKS and improving the image of the Jakarta PKS.
\end{abstract}

Keywords : Media, Communication, Political Party, Image

\begin{abstract}
Abstrak
Peran dan fungsi Partai Politik akhir-akhir ini telah terdegradasi karena adanya stereotip negatif terhadap Partai Politk, termasuk Partai Keadilan Sejahtera (PKS). Hal ini karena beberapa kader PKS tertangkap Komisi Pemberantasan Korupsi (KPK) dalam pemberitaan media massa. Selain itu pengkaderan Partai Politik termasuk Partai Keadilan Sejahtera (PKS) sebagai tempat lahirnya kepemimpinan nasional terlihat kurang maksimal. Untuk itu peneliti tertarik membahas pemanfaatan media komunikasi humas Partai Keadilan Sejahtera (PKS) melalui media dalam meningkatkan citra lembaga. Berdasarkan konsteks tersebut, penelitian ini bertujuan untuk mengetahui Pemanfaatan Media Komunikasi Humas Partai Keadilan Sejahtera (PKS) DKI Jakarta Dalam Meningkatkan Citra dan menganalisis faktor-faktor yang mendukung Pemanfaatan Media Komunikasi Humas Partai Keadilan Sejahtera (PKS) DKI Jakarta. Penelitian ini menggunakan metode penelitian kualitatif dengan teknik pengumpulan data berupa wawancara, observasi, dokumentasi dan studi kepustakaan. Wawancara dilakukan pada 4 (empat) orang informan mewakili Bagian Humas PKS baik di tingkat Provinsi DKI Jakarta dan DPC PKS tingkat Kecamatan Pulogadung. Hasil penelitian menunjukkan bahwa pemanfaatan media Pemanfaatan Media Komunikasi terutama Media Sosial oleh Humas PKS antara lain yaitu PKS Foto, PKS TV, Relawan Digital, Relawan Literasi, PKS Art, dan pembuatan video pendek yang diiklankan. Faktor pendukung pemanfaatan media komunikasi yaitu SDM kader-kader PKS yang solid serta sumber
\end{abstract}


dana yang mencukupi untuk menunjang pemanfaatan media komunikasi terutama media sosial dalam mengurangi stereotip negatif masyarakat terhadap PKS dan meningkatkan citra PKS DKI Jakarta.

Kata Kunci : Media, Komunikasi, Partai, Citra

\section{PENDAHULUAN}

Akhir-akhir ini terdapat trend politik masyarakat Jakarta tidak menggunakan hak pilih dalam Pemilu. Berbagai pelaksanaan pemilihan kepala daerah, pemilihan calon anggota legislatif, pemilihan umum maupun pemilihan presiden memperlihatkan tingkat golput yang cukup tinggi. Komisi Pemilihan Umum (KPU) DKI Jakarta dalam laporan rekapitulasi penghitungan suara dan hasilnya keikutsertaan warga dalam pemilihan legislatif (9/4/2014) lalu hanya mencapai 64,33 persen (data KPU : 2014). Data ini jauh dari Target KPU DKI Jakarta yaitu $75 \%$. Rendahnya kepercayaan masyarakat terhadap lembaga-lembaga politik, eksekutif, birokrasi, lembaga peradilan, lembaga perwakilan maupun partai politik adalah sebuah hambatan besar bagi perkembangan demokrasi. Rendahnya kepercayaan terhadap sistem politik yang ada adalah sebuah kondisi yang mengkhawatirkan bagi masa depan demokrasi.

Penelitian Akhirul Aminulloh berjudul Strategi Komunikasi Politik Partai Politik Pada Pemilu Legislatif 2009 (Studi tentang Penyikapan Partai PKS terhadap UU No. 10 Tahun 2008 tentang Pemilu Anggota DPR, DPRD, dan DPD), menunjukkan Pemilihan umum legislatif 2009 diikuti oleh banyak partai politik yang berimplikasi pada ketatnya persaingan antar partai politik dalam perebutan suara pemilih. Segala strategi, taktik, dan cara dilakukan oleh semua partai politik untuk memenangkan pemilu. Adanya putusan Mahkamah Konstitusi (MK) tentang suara terbanyak, sedikit banyak ikut berperan terhadap perubahan strategi komunikasi politik partai dalam kampanye menjelang pemilu. Penelitian Aminulloh ini bertujuan untuk mengetahui strategi komunikasi politik Partai Keadilan Sejahtera (PKS) pada pemilu legislatif 2009, terutama penyikapan partai terhadap UU No. 10 Tahun 2008 tentang Pemilu Anggota DPR, DPRD, dan DPD. Penelitian ini dilaksanakan di DPW PKS Yogyakarta.

Terkait hal tersebut, kajian komunikasi politik merupakan pengembangan dalam kajian komunikasi. Komunikasi berasal dari bahasa latin communis yang berarti sama, communico, communicatio, atau communicare yang berarti membuat sama (to make common). Kata communis menjadi istilah yang kerap digunakan sebagai asal usul kata komunikasi yang merupakan akar dari sejumlah kata latin lainnya yang semakna. Dalam hal ini, komunikasi menyarankan bahwa suatu pemikiran, makna, atau suatu pesan dianut secara sama (Mulyana, 2005 : 4). Dipandang dari dimensi komunikator, komunikator yang efektif adalah komunikator yang memiliki kredibilitas (source credibility) dan daya Tarik (source attractiveness) (Shoelhi 2011 : 41). Menurut Cangara (2004:119) bahwa media komunikasi dapat dibedakan atas empat macam, yaitu media antarpribadi, media kelompok, media publik, dan media massa.

Sementara itu, partai politik yang menjadi fokus penelitian ini merupakan bagian dari organisasi politik. Organisasi menurut Robbins (2001:4) diartikan sebagai suatu unit (satuan) sosial yang dikoordinasikan dengan sadar, yang terdiri dari dua orang atau lebih, yang berfungsi atas dasar yang relatif terus menerus untuk mencapai suatu tujuan atau serangkaian tujuan bersama. Komunikasi organisasi merupakan perilaku pengorganisasian yang terjadi dan bagaimana mereka yang terlibat dalam proses itu bertransaksi dan memberi makna atas apa yang terjadi (Pace \& Faules, 2001: 31-33).

Kajian komunikasi politik sendiri merupakan sintesa antara ilmu komunikasi dan ilmu politik. Ilmu politik adalah ilmu 
Saktisyahputra, Pemanfaatan Media Komunikasi Humas Partai Keadilan Sejahtera (PKS) ...

yang mempelajari politik atau politics atau kepolitikan. Politik adalah usaha menggapai kehidupan yang baik. Di Indonesia kita teringat pepatah gemah ripah loh jinawi. Orang Yunani Kuno terutama Plato dan Aristoteles menamakan sebagai en dam onia atau the good life. Mengapa politik dalam arti ini begitu penting ? Karena sejak dahulu kala masyarakat mengatur kehidupan kolektif dengan baik, mengingat masyarakat sering menghadapinya terbatasnya sumber alam, atau perlu dicari satu cara distribusi sumber daya agar semua warga merasa bahagia dan puas. Ini adalah politik. Bagaimana caranya mencapai tujuan yang mulia itu ? Usaha itu dapat dicapai dengan berbagai cara, yang kadang - kadang bertentangan satu dengan yang lainnya. Akan tetapi semua pengamat setuju bahwa tujuan itu hanya dapat dicapai, jika memiliki kekuasaan suatu wilayah tertentu (negara atau sistem politik). Kekuasaan itu perlu dijabarkan dalam keputusan mengenai kebijakan yang akan menentukan pembagian atau alokasi dari sumber daya yang ada. Filsuf seperti Plato dan Aristoteles menganggap politics sebagai suatu usaha untuk mencapai masyarakat politik yang baik. Pada umumnya dapat dikatakan bahwa politik (politics) adalah usaha untuk menentukan peraturan-peraturan yang dapat diterima oleh sebagian besar warga, untuk membawa masyarakat ke arah kehidupan bersama yang harmonis. (Miriam 2017 : 13-15). Sementara menurut Dan Nimmo, politik adalah kegiatan secara kolektif yang mengatur perbuatan mereka dalam kondisi konflik (Ghazaly 2014 : 35).

Apabila definisi komunikasi dan definisi politik itu kita kaitkan dengan komunikasi politik, maka akan terdapat suatu rumusan sebagai berikut : Komunikasi politik adalah komunikasi yang diarahkan kepada pencapaian suatu pengaruh sedemikian rupa, sehingga masalah yang dibahas oleh jenis kegiatan komunikasi ini, dapat mengikat semua warganya melalui suatu sanksi yang ditentukan bersama oleh lembaga-lembaga politik (Astrid, S. Soesanto, 1980:2).

Mengenai komunikasi politik ini (political communication) Kantaprawira
(1983:25) memfokuskan pada kegunaannya, yaitu untuk menghubungkan pikiran politik yang hidup dalam masyarakat, baik pikiran intra golongan, institusi, asosiasi, ataupun sektor kehidupan politik masyarakat dengan sektor kehidupan politik pemerintah. Pemilu pertama di era Orde Baru tahun 1971 secara legal merujuk pada Undang-Undang Nomor 15 Tahun 1969 tentang Pemilihan Umum Anggota-Anggota Badan Permusyawaratan/Perwakilan Rakyat. Aturan soa kampanye dalam UU itu termuat dalam Bab VI soal Kampanye Pemilihan dalam bentuk yang sangat sederhana (Danial 2009 : 106).

Partai politik adalah organisasi atau golongan yang berusaha untuk memperoleh dan menggunakan kekuasaan. (Miriam 1998 : 16). Sigmund Neuman dalam (Harry Eckstein dan David E. Apter 1963 : 352) mengatakan bahwa Partai politik adalah organisasi tempat kegiatan politik yang berusaha untuk menguasai kekuasaan pemerintah serta merebut dukungan rakyat atas dasar persaingan melawan suatu golongan atau golongan-golongan lain yang tidak sepaham. Secara etimologis, sosialisasi politik adalah urusan negara. Urusan negara yang dimaksud adalah semua aspek kehidupan bermasyarakat, berbangsa dan bernegara. Michael Rush dan Phillip Althof menjelaskan bahwa sosialisasi politik adalah proses oleh pengaruh seorang individu mengenai sistim politik, yang kemudian menentukan persepsi serta reaksinya terhadap gejala-gejala politik (Mukarom 2016 : 207-208).

Kampanye Politik adalah sebuah upaya terorganisasi yang dilakukan oleh sebuah kelompok (agen perubahan) yang bertujuan memersuasi pihak lainnya (target) untuk menerima, memodifikasi, atau menolak ide-ide, sikap-sikap, tindakan-tindakan praktis, dan perilaku tertentu" - Kotler dan Roberto (dalam Cangara 2009 : 284).

Pemasaran politik dapat didefinisikan sebagai penerapan prinsip dan prosedur pemasaran dalam kampanye politik oleh berbagai individu dan organisasi (Kaid 2004 : 18). Menurut Haroen (2014 : 48) marketing politik adalah penerapan konsep dan metode 
marketing ke dalam dunia politik. Menurut Firmanzah (2008 : 203), dalam proses Political Marketing digunakan penerapan 4P bauran marketing, yaitu 1. Produk (product) berarti partai, kandidat dan gagasan-gagasan partai yang akan disampaikan konstituen. 2. Promosi (promotion) adalah upaya periklanan, kehumasan dan promosi untuk sebuah partai yang di mix sedemikian rupa sesuai dengan kebutuhan masyarakat. 3. Harga (Price), mencakup banyak hal, mulai ekonomi, psikologis, sampai citra nasional. 4. Penempatan (Place), berkaitan erat dengan cara hadir atau distribusi sebuah partai dan kemampuannya dalam berkomunikasi dengan para pemilih.

Sementara itu, penelitian ini tertarik untuk melihat upaya partai poltik dalam meningkatkan citra. Citra sendiri menurut $G$. Sach dalam Soemirat dan Ardianto (2007:171) citra adalah pengetahuan mengenai kita dan sikap-sikap terhadap kita yang mempunyai kelompok-kelompok yang berbeda.

Berdasarkan hal tersebut, peneliti tertarik untuk mengetahui Pemanfaatan Media Komunikasi Humas Partai Keadilan Sejahtera (Pks) Dki Jakarta Dalam Meningkatkan Citra lembaga.

\section{METODE PENELITIAN}

Metode yang digunakan dalam penelitian ini adalah metode kualitatif interpretif dengan menggunakan studi kasus. Adapun analisisnya adalah model analisis interaktif. Kirk dan Miller (Moleong : 2000 : 3-8) mendefinisikan bahwa penelitian kualitatif adalah tradisi tertentu dalam ilmu pengetahuan sosial yang secara fundamental bergantung pada pengamatan pada manusia dalam kawasannya sendiri berhubungan dengan orang-orang tersebut dalam bahasanya dan segala macam peristilahannya.

Sementara menurut Lincoln dan Guba (1985:39) penelitian kualitatif merupakan penelitian yang dilakukan pada latar alamiah atau pada konteks dari suatu keutuhan (entity). Dalam buku Denzin \& Lincoln, interpretif adalah menggunakan kata 'bagaimana' dan 'apa' mengenai realitas sosial yang dipusatkan pada bagaimana secara metodologi mengkonstruksikan pengalamanpengalamannya dan dunianya dan dalam bentuk arti dan kehidupan institusional yang dapat menginformasikan dan menajamkan kenyataan.

Jadi dapat dikatakan penelitian kualitatif - interpretif adalah penelitian yang menggunakan data-data deskriptif berupa kata-kata tertulis, lisan dari orang lain dan perilaku yang dapat diamati serta data yang berdasarkan pengalaman orang lain.

Esensi tujuan penelitian ini adalah melakukan pemahaman (understanding) terhadap subyek yang diteliti melalui studi komparatif dengan menggunakan tiga variabel yaitu structure, conduct dan performance. Dengan kata lain, pendekatan ini diarahkan pada data kata dan individu tersebut secara utuh. Dengan demikian, tidak mengisolasikan individu atau organisasi kedalam variabel atau hipotesis tetapi perlu memandangnya sebagai bagian dari suatu keutuhan.

Karena itu penelitian ini berusaha memberikan gambaran mengenai Pemanfaatan Media Komunikasi Humas Partai Keadilan Sejahtera (PKS) DKI Jakarta dalam meningkatkan citra dan Faktor-faktor apa saja yang mendukung Pemanfaatan Media Komunikasi Humas Partai Keadilan Sejahtera (PKS) DKI Jakarta dalam meningkatkan citra lembaga.

Untuk lebih mengetahui sejauh mana Pemanfaatan Media Komunikasi yang dilakukan oleh Dewan Pimpinan Wilayah (DPW) Partai Keadilan Sejahtera (PKS) DKI Jakarta, maka penulis menetapkan narasumber atau informan yang dianggap memahami permasalahan untuk dipaparkan kepada penulis, informan yang ditetapkan adalah sebagai berikut:

1. Ketua Bidang Humas DPW PKS tingkat Provinsi DKI Jakarta

2. Ketua Bidang Humas PKS tingkat Kota Jakarta Timur

3. Ketua DPC PKS tingkat Kecamatan Pulogadung Jakarta Timur

4. Ketua DPRa PKS tingkat Kelurahan Pulogadung Jakarta Timur 
Saktisyahputra, Pemanfaatan Media Komunikasi Humas Partai Keadilan Sejahtera (PKS) ...

Teknik pengumpulan data dalam penelitian ini dilakukan dengan beberapa metode yaitu: 1. Wawancara Mendalam ; menurut Harsono, wawancara merupakan proses pengumpulan data yang langsung memperoleh informasi langsung dari sumbernya. Menurut Mantja (dalam Harsono, 2008: 162), wawancara mendalam merupakan percakapan terarah yang tujuannnya untuk mengumpulkan informasi etnografi. 2. Observasi ; Teknik pengumpulan data ini digunakan untuk menjaring data yang diperlukan guna melengkapi data dari wawancara. Menurut Sutopo (dalam Harsono, 2008: 164), observasi merupakan kegiatan pengamatan yang dilakukan oleh peneliti, di mana peneliti berperan aktif dalam lokasi studi sehingga benar-benar terlihat dalam kegiatan yang ditelitinya. 3. Dokumentasi ; Dokumentasi adalah pengambilan data yang diproses melalui dokumen-dokumen. Metode dokumentasi dipakai untuk mengumpulkan data dari sumber-sumber dokumen yang mungkin mendukung atau bahkan berlawanan dengan hasil wawancara (Harsono, 2008: 165).

Untuk analisis data, merujuk pada pandangan Taylor, (1975: 79) mendefinisikan analisis data sebagai proses yang merinci usaha secara formal untuk menemukan tema dan merumuskan hipotesis (ide) seperti yang disarankan dan sebagai usaha untuk memberikan bantuan dan tema pada hipotesis. Teknik analisis data dalam penelitian ini menggunakan Miles dan Huberman (Emzir 2010,13) menyatakan bahwa terdapat tiga macam kegiatan analisis data kualitatif. Analisis data dalam penelitian ini menggunakan teknik analisis data dalam situs yang dikembangkan oleh Miles Huberman. Data yang sudah terkumpul dibuat dalam matriks. Dalam matriks akan disajikan penggalan-penggalan data deskriptif sekitar peristiwa atau pengalaman tertentu yang menyekat data sebelum dan sesudahnya. Setelah data dimasukkan kedalam matriks selanjutnya di buat daftar cek (Miles Huberman, 2007: 139-140).

\section{HASIL DAN PEMBAHASAN}

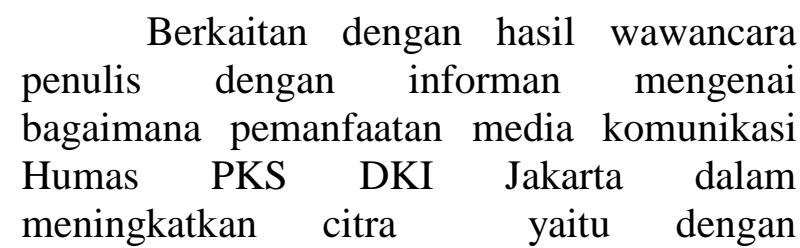
pemanfaatan media sosial dengan beragam content serta dilakukan oleh Humas PKS baik di tingkat DPP maupun di Humas PKS Wilayah DKI Jakarta. Dengan kecanggihan teknologi komunikasi saat ini memungkinkan pembuatan content media yang beragam bahkan hanya melalui handphone. Hal ini seperti tertuang dalam wawancara dengan Bapak Zakaria Ketua Bidang (Kabid) Humas DPW PKS DKI Jakarta :

"Media Komunikasi dalam konteks Pemilu Legislatif untuk Partai itu tentunya akan dimanfaatkan seoptimal mungkin pemanfaatannya lewat apa untuk meningkatkan citra itu dibuatkan dengan publikasi. Kemudian video-video pendek, visual art itu kemudian ditampilkan keluar, ya harus diiklankan. Kalau tidak diiklanlan orang ga semua baca karena berlaku hukum Eco Chamber dalam sosial media itu gaungnya hanya di sekitaran di lingkaran itu saja. Orang luar tidak bisa melihat karya dari yang sudah dibuatkan untuk meningkatkan citra. Jadi Humas PKS DPP dan kemudian ke Humas PKS DKI Jakarta itu ada 5 susunan koordinator dari masing-masing jenis pemanfaatan media. 1.PKS Foto 2. PKS TV 3. Relawan Digital 4. Relawan Literasi dan 5. PKS Art. Nah 5 inilah yang saling berintegrasi focus ke situ, yang masing-masing ada koordinatornya yang melakukan produk-produk kreatif yang dikeluarkan untuk meningkatkan citra partai dan tentunya dari tahun ke tahun semakin massif lagi, karena sekarang kemudahan-kemudahan 
sudah banyak seperti halnya membuat video dari handphone membuat visual art dari handphone juga sudah banyak ini jadi pola baru Partai Politik dalam meningkatkan citra"

Sementara terkait Faktor-faktor apa saja yang mendukung Pemanfaatan Media Komunikasi Humas PKS DKI Jakarta dalam Meningkatkan Citra adalah terdapat beberapa faktor, antara lain : Kualitas Sumber Daya Manusia (SDM) yang dimiliki PKS, dukungan dana, dan alat-alat pendukung kreativitas. PKS sangat memperhatikan kualitas SDM. Hal ini tergambar melalui kader-kader PKS yang dilatih melalui Sekolah Digital, sehingga kader memiliki bekal keterampilan digital. Faktor - faktor pendukung tersebut merangkum dalam wawancara dengan Bapak Zakaria Ketua Bidang (Kabid) Humas DPW PKS DKI Jakarta, sebagai berikut :

"Faktor-faktor yang mendukung tentunya SDM ya. SDM itu kaderkader PKS sendiri dilatih lewat Sekolah Digital, mengembangkan diri masing-masing. Memang PKS tidak selamanya mendampingi, setelah keluar dari Sekolah Digital SDM tersebut justru mengembang dirinya masingmasing lewat apapun, misalnya lewat jaringan-jaringan bisnis yang mereka punya atau kreativitas-kreativitas yang lain. Inilah yang luar biasa dimanfaatkan oleh kader-kader $P K S$, dan saya mengalami sendiri waktu Pilkada DKI Jakarta 2017 kemarin, ketika kami menjadi Tim Peliput nya Anies-Sandi. Kalau Tim Peliput Anies-Sandi dari Parpol lain menggunakan orang lain bukan kader sendiri seperti wartawan, tapi PKS menggunakan kader-kader sendiri menjadi Tim Liputan CagubCawagub DKI Jakarta 2017 kemarin. Nah itu yang saya bilang bahwa faktor penentunya adalah SDM, dan setelah itu juga ada sumber dana yang dicukupkan SDM tersebut. Dan selain SDM, juga ada alat-alat yang mendukung kreativitas yang dibuat".

Selain faktor-faktor pendukung diatas, beberapa pendekatan juga dilakukan Humas PKS yakni untuk media cetak dan elektronik, PKS melakukan media relation dengan kunjungan ke media dan komunitas media, serta mengirimkan press release. Sedangkan untuk media sosial, Humas PKS membekali kader partai, relawan, dan tim sukses dengan pelatihan, sosialisasi UU ITE dan kampanye "Ayo Posting Positif". Hal ini sebagaimana diungkapkan Bapak Awi Ketua Bidang (Kabid) Humas DPD PKS Jakarta Timur, sebagai berikut :

"Untuk media cetak dan
elektronik kami melakukan
kunjungan ke lokasi kerja dan
masuk dalam komunitas
wartawan media tersebut, dan
saling berbagi informasi terutama
press release terkait kegiata dari
partai dan para Calon Anggota
Dewan (CAD) Partai. Untuk
media social, kami banyak
melakukan pelatihan kepada para
kader, relawan, dan Timses para
CAD baik tema, konten media,
dan distribusinya, serta
sosialisasi UU ITE.
Mengkampanyekan tagline "Ayo
Posting Positif” dalam berbagai
kanal media struktur organisasi
partai dan kader."

Berbagai upaya meningkatkan citra PKS dilakukan, salah satunya adalah untuk pemenangan pada Pemilu Legislatif. Upaya yang dilakukan yakni memanfaatkan seluruh unsur media baik media mainstream maupun nonmainstream. Sosialisasi gagasan-gagasan PKS menjadi salah satu upaya "memasarkan" PKS pada konstituen. Hal ini sebagaimana 
Saktisyahputra, Pemanfaatan Media Komunikasi Humas Partai Keadilan Sejahtera (PKS) ...

yang dikemukakan Bapak Awi Humas DPD PKS Jakarta Timur, sebagai berikut :

"Program pemenangan Pemilu

Legislatif Partai Keadilan

Sejahtera (PKS) berupa

menaikkan popularitas dan

elektabilitas Partai dan para

Calon Anggota Dewan (CAD)

nya. Hal ini sangat membutuhkan

media, baik media mainstream dan nonmainstream. Program sosialisasi politik gagasan PKS yang telah di launching sebagai sarana memasarkan kepada para konstituen dan target audiens partai. Kebijakan partai yang sangat concern dengan ajakan bekerjasama dan berkomunikasi dengan semua elemen bangsa."

Upaya-upaya meningkatkan citra partai dilakukan dengan melibatkan kaderkader. Karenanya PKS senantiasa meningkatkan kemampuan dan keterampilan para kader khususnya dalam memanfaatkan media sosial melalui berbagai pelatihanpelatihan untuk memaksimalkan media komunikasi. Hal ini sebagaimana tertuang dalam wawancara dengan Bapak Zelfiadi Risja Ketua DPC PKS Pulogadung Jakarta Timur, sebagai berikut :

"Setahu saya saat ini penggunaan media sudah semakin baik dari periode-periode sebelumnya dimana saat ini mulai dari tingkat DPP Pusat, DPW Provinsi, DPD Kabupaten/Kota. Kader PKS sudah sering kali diundang di tingkat Kecamatan untuk Pelatihan-pelatihan yang memaksimalkan media komunikasi, kayak trainingtraining untuk bagaimana pemaksimalan sosial media mulai dari Instagram, Facebook, Youtube. Jadi, sering diajarkan bagaimana supaya media komunikasi ini bisa familiar untuk kalangan kader, khususnya karena sekali lagi saat ini mungkin masih belum maksimal penggunaan sosial media yaitu media komunikasi. Sehingga menurut saya, sudah baik, tapi harus terus digencarkan, dimassifkan untuk bagaimana seluruh kader benar-benar bisa mengoptimalkan media komunikasi ini untuk meningkatkan citra PKS DKI Jakarta".

Besarnya peran para kader PKS menjadi Faktor-faktor yang mendukung Pemanfaatan Media Komunikasi Humas PKS DKI Jakarta dalam Meningkatkan Citra. Faktor Sumber Daya Manusia (SDM) seperti Kader-kader PKS dan Kepemilikan Media Komunikasi seperti TV dan Radio sangat menentukan dalam peningkatan Citra PKS. Hal ini sebagaimana dikutip dari wawancara dengan Bapak Zelfiadi Risja Ketua DPC PKS Pulogadung Jakarta Timur, sebagai berikut :

"Kalau bicara sekarang sudah banyak ya, selain bicara personal pribadi-pribadi dikencangkan, setiap kader memiliki account facebook, punya gmail, punya youtube. Kalau ada berita apaapa masukkin di youtube atau streaming di facebook atau di $I G$ atau di twitter. Silahkan dimaksimalkan oleh personal, tapi secara PKS juga udah banyak juga sekarang niy secara terpusat PKS punya PKS TV. Secara daerah juga saya perhatiin juga punya TV-TV daerah, tapi memang karena kita ini belum bisa punya TV komersial, jadi tantangan kita bagaimana ke depan PKS punya TV juga, punya radio juga, sehingga seluruh elemen ataupun segmen-segmen bisa tahu PKS. Jadi mudahmudahan ke depan, kalau PKS insya allah menang kita punya $T V$, sehingga seluruh masyarakat benar-benar bisa merasakan 
bagaimana manfaatnya ketika PKS itu memimpin".

Meski upaya-upaya telah dilakukan Humas PKS, namun ternyata dinilai masih kurang gencar penggunaan media komunikasi terutama sosial media untuk bisa dimaksimalkan kader-kader PKS dalam peningkatan citra. Hal ini seperti dikemukakan Bapak Andika Ketua DPR PKS Pulogadung Jakarta Timur :

"Sekarang ini sepertinya memang masih kurang gencar, untuk sosialisasi Partai ataupun Calon Anggota Legislatif yang diusung oleh Partai Keadilan Sejahtera (PKS). Spanduk-spanduk masih bisa dibilang jarang, masih kurang gencar mensosialisasikan calon anggota dewannya. Begitu juga di media sosial seperti Facebook. Tentu ini bukan hanya kerja humasnya saja yang kurang terlihat, tapi juga kader-kadernya juga kurang untuk menanggapi, merespon, melike dan menshare. Jadi terasa kurang menjadi terlihat di masyarakat di medsosnya. Ini kesimpulannya memang kurang gencar. Memang ini bukan hanya tugas humas saja tapi seluruh kader berkewajiban mendukung bagian humas tersebut karena media sosial juga harus bersama-sama seluruh lapisan kader turut meramaikan media sosial”.

Selain itu, guna meningkatkan citra PKS, maka PKS membangun jaringan diantara para kader, seperti grup relawan, grup saksi dan lain-lain. Kehadiran jaringan ini menjadi penting dalam mendukung kerja Humas PKS. Dan tentu, para kader harus dikuatkan dengan penguasaan keterampilan media sosial melalui pelatihan. Hal ini sebagaimana diungkapkan Bapak Andika Ketua DPRa PKS Pulogadung Jakarta Timur, sebagai berikut :

"Faktor-faktor yang mendukung tentu adalah jaringan keaktifan kader sampai akar rumput DPRa dan Koordinator $R W$ (Korwe) di sini lebih ditekankan kembali kader harus online, harus ada yang diambil di media sosialnya baik di facebooknya atau dari media sosialnya. Jadi setiap Ketua DPRa itu harus punya grup wa relawan, grup wa saksi seperti itu, agar mempunyai jaringan-jaringan yang mencakup banyak warganya. Jadi, selain humas yang bekerja, kader dan simpatisan ini harus aktif di media sosial. Tentu diperhatikan juga barangkali ada kader juga yang tidak mempunyai alat komunikasi, kita bisa subsidi silang. Dengan diseriuskan media sosial harus kita kuasai untuk media elektronik yang lainnya mungkin seperti pembuatan video-video pendek. Kader harus diikutkan juga dalam pelatihannya. Jadi kader harus bisa membuat flyer sendiri. Untuk membuat isu-isu yang banyak, Setiap hari membuat isu yang baru itu membutuhkan keaktifan kader - kader sendiri yang sangat mendukung”.

Berdasarkan hasil penelitian diatas, maka berikut adalah Pemanfaatan Media Komunikasi yang dilakukan Humas PKS dalam meningkatkan citra lembaga : 
Saktisyahputra, Pemanfaatan Media Komunikasi Humas Partai Keadilan Sejahtera (PKS) ...

Tabel 1. Pemanfaatan Media Komunikasi Dalam meningkatkanCitra PKS

\begin{tabular}{lll}
\hline \multicolumn{1}{c}{$\begin{array}{c}\text { Pemanfaatan Media } \\
\text { Komunikasi }\end{array}$} & $\begin{array}{c}\text { Faktor- faktor pendukung } \\
\text { Pemanfaatan Media }\end{array}$ & $\begin{array}{l}\text { Upaya meningkatkan Citra } \\
\text { PKS melalui Media } \\
\text { Komunikasi }\end{array}$ \\
\hline Media Mainstream & $\begin{array}{l}\text { Kualitas Sumber Daya } \\
\text { Manusia (SDM) yang } \\
\text { dimiliki PKS }\end{array}$ & $\begin{array}{l}\text { Pelatihan keterampilan media } \\
\text { pada kader, simpatisan, dan } \\
\text { pengurus partai }\end{array}$ \\
$\begin{array}{l}\text { Sosial Media : IG, Facebook, } \\
\text { Twitter, Whatsapp, Youtube }\end{array}$ & Dukungan dana & $\begin{array}{l}\text { Media relation dengan } \\
\text { Membangun jaringan dengan }\end{array}$ \\
& & $\begin{array}{l}\text { komunitas wartawan dan } \\
\text { press release }\end{array}$ \\
$\begin{array}{l}\text { PKS Foto, PKS TV, Relawan } \\
\text { Digital, Relawan Literasi } \\
\text { dan PKS Art. }\end{array}$ & Alat - alat pendukung & $\begin{array}{l}\text { Meningkatkan keaktifan } \\
\text { kader sehingga mampu } \\
\text { kreativitas }\end{array}$ \\
& & $\begin{array}{l}\text { membuat flyer sendiri, } \\
\text { membuat isu-isu berkualitas } \\
\text { setiap hari }\end{array}$ \\
\hline
\end{tabular}

Berdasarkan hasil penelitian diatas, maka sebagaimana yang disampaikan oleh Cangara (2004:119) bahwa media komunikasi dapat dibedakan atas empat macam, yaitu media antarpribadi, media kelompok, media publik, dan media massa. Sedangkan Michael Rush dan Phillip Althof menjelaskan bahwa sosialisasi politik adalah proses oleh pengaruh seorang individu mengenai sistim politik, yang kemudian menentukan persepsi serta reaksinya terhadap gejala-gejala politik (Mukarom 2016 : 207-208). Jika dikaitkan dengan konsep tersebut, maka Pemanfaatan Media Komunikasi Humas PKS DKI Jakarta dalam meningkatkan citra yaitu Pemanfaatan Media Komunikasi terutama Media Sosial dengan 5 Unsur yang disampaikan Bapak Zakaria yaitu 1.PKS Foto; 2. PKS TV 3; Relawan Digital; 4. Relawan Literasi; dan 5. PKS Art serta pembuatan video pendek yang juga diiklanlan menjadi bagian dari sosialisasi politik Humas PKS DKI Jakarta dalam meningkatkan citra.

Sebagaimana dalam Pemasaran politik dapat didefinisikan sebagai penerapan prinsip dan prosedur pemasaran dalam kampanye politik oleh berbagai individu dan organisasi (Kaid 2004 : 18). Menurut Haroen (2014 : 48) marketing politik adalah penerapan konsep dan metode marketing ke dalam dunia politik. Menurut Firmanzah (2008 : 203), dalam proses Political Marketing digunakan penerapan 4P bauran marketing, maka jika dikaitkan dengan penelitian ini : 1. Produk (product) berarti partai, kandidat dan gagasangagasan partai yang akan disampaikan konstituen. 2. Promosi (promotion) adalah upaya periklanan, kehumasan dan promosi untuk sebuah partai yang di mix sedemikian rupa sesuai dengan kebutuhan masyarakat. 3 . Harga (Price), mencakup banyak hal, mulai ekonomi, psikologis, sampai citra nasional. 4. Penempatan (Place), berkaitan erat dengan cara hadir atau distribusi sebuah partai dan kemampuannya dalam berkomunikasi dengan para pemilih.

Faktor-faktor yang mendukung peningkatan citra PKS tentunya SDM. Dimana, SDM yang terdiri dari kader-kader PKS sendiri dilatih lewat Sekolah Digital untuk mengembangkan diri masing-masing. Selain faktor SDM, sumber dana yang cukup serta adanya alat-alat yang mendukung kreativitas menjadi faktor yang mendukung peningkatan citra PKS.

\section{SIMPULAN}

Kesimpulan penelitian ini bahwa Pemanfaan Media Komunikasi Partai Keadilan Sejahtera (PKS) DKI Jakarta dalam meningkatkan citra yaitu melalui pemanfaatan media mainstream, sosial media antara lain IG, Facebook, Twitter, dan Youtube serta 
memanfaatkan media PKS Foto, PKS TV, Relawan Digital, Relawan Literasi, PKS Art, dan pembuatan video pendek yang diiklankan. Upaya pemanfaatan media dalam meningkatkan citra PKS dilakukan dengan peningkatan kualitas SDM melalui pelatihan, melakukan media relations dan mengaktifkan kader dalam membuat flyer maupun isu-isu konstruktif setiap hari. Sementara itu, faktor faktor yang mendukung Pemanfaan Media Komunikasi Partai Keadilan Sejahtera (PKS) DKI Jakarta dalam meningkatkan citra yaitu faktor Sumber Daya Manusia (SDM), sumber dana yang cukup, serta adanya alat-alat yang mendukung kreativitas para kader, simpatisan dan pengurus partai.

\section{DAFTAR PUSTAKA}

Akhirul Aminulloh, S.Ikom, 2010. Strategi Komunikasi Politik Partai Politik Pada Pemilu Legislatif 2009 (Studi tentang Penyikapan Partai PKS terhadap UU No. 10 Tahun 2008 tentang Pemilu Anggota DPR, DPRD, dan DPD). Surakarta : Universitas Sebelas Maret.

Agus Salim, 2006, Teori dan Paradigma Penelitian Sosial: Buku Sumber Untuk Penelitian Kualitatif (edisi kedua, Agustus 2006), Tiara.

Budiarjo, Miriam, 2017, Dasar-dasar Ilmu Politik Edisi Revisi, Jakarta : Gramedia Pustaka Utama.

Bungin, Burhan,2010,Penelitian Kualitatif : Komunikasi, Ekonomi,Kebijakan Publik dan Ilmu Sosial lainnya. Jakarta: Kencana Prenada Media.

Cangara, Hafied. 2004. Pengantar Ilmu Komunikasi. Jakarta : Kencana Prenada.

Danial, Akhmad. 2009, Iklan Politik TV Modernisasi Kampanye Politik Pasca Orde Baru. Yogyakarta : LKIS

Emzir. 2010. Metodologi Penelitian Pendidikan:Kuantitatif dan Kualitatif. Jakarta: Rajawali Pers.

Firmanzah. 2008. Marketing Politik. Yayasan Obor Indonesia. Jakarta

Ghazaly. 2014. Ilmu Komunikasi Politik. Yogyakarta. Andi.
Haroen, Dewi. 2014. Personal Branding. Jakarta : PT Gramedia Pustaka Utama.

https://megapolitan.kompas.com/read/2014/04 /28/0851147/Warga.Jakarta.Masih.Ba nyak.yang.Golput.

Kaid, Lynda. 2004. Handbook of Political Communication Research. Lawrence Elbaum Associates : London.

Miles, Mattew B dan Amichael Huberman. 2007. Analisis Data Kualitatif Buku Sumber tentang Metode-Metode Baru. Terjemahan Tjetjep Rohendi Rohisi. Jakarta : Universitas Indonesia.

Moleong, Lexy J. 2000. Metodologi Penelitian Kualitatif. Bandung: PT. Remaja Rosdakarya.

Mukarom, Zaenal. 2016. Komunikasi Politik. Bandung. Pustaka Setia

Mulyana, Deddy. 2005. Ilmu Komunikasi Suatu Pengantar. Bandung : Remaja Rosdakarya

Robbins, Stephen P. 2001. Perilaku Organisasi, Edisi 8. Prentice Hall, Jakarta

Ruslan,Rosady. 2008. Manajemen Public Relations \& Media Komunikasi. Jakarta : PT Rajagrafindo Persada.

R. Wayne Pace dan Don F. Faules. 2001. Komunikasi Organisasi (terjemahan). Bandung: Rosdakarya

Soemirat, Soleh \& Ardianto, Elvinaro, 2007, Dasar-Dasar Public Relations, Bandung, Rosdakarya

Shoelhi, Mohammad. 2011. Diplomasi Praktik Komunikasi Internasional, Bandung, Simbiosa Rekatama Media 